Gi rask respons på artikler gjennom artikkelens kommentarfelt på tidsskriftet.no. Respons som er postet innen én måned etter at artikkelen er publisert, vurderes for publisering som Brev til redaktøren i papirutgaven.

Redaksjonen forbeholder seg retten til å foreta redaksjonelle endringer.

Forfattere av vitenskapelige artikler har tilsvarsrett, jf. Vancouver-gruppens regler.

\section{La oss få flere varslere}

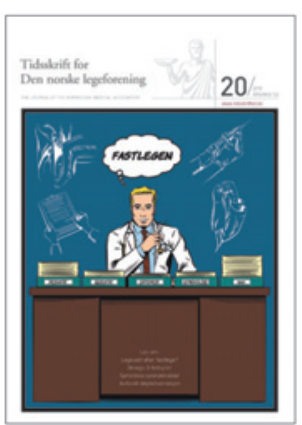

I Tidsskriftet nr. 20/2012 får vi en skremmende tilstandsrapport (1). Er utviklingen ved norske sykehus virkelig slik at et smidig organisasjonssystem går foran hensynet til pasientens ve og vel? For undertegnede som ikke har kontakt med helsevesenet annet enn ved sykdom enten egen eller i familie/vennekrets er dette høyst foruroligende informasjon.

Foruroligende fordi varslerartikkelen tyder på et beinhardt sykehusmiljø hvor viktige innvendinger og korrektiv ikke bare neglisjeres, men kan føre til tragiske konsekvenser for den som varsler. Siden jeg ikke kjenner nærmere til norske sykehus, stiller jeg meg naturlig nok spørsmålet om varsleren er en urokråke som av egen interesse eller fikse ideer strør sand i et maskineri som egentlig går i en god og riktig retning. Men det varsles også fra andre innen helsevesenet. I Klassekampen for 12. oktober i år påpeker Berit Foss, førsteamanuensis ved Institutt for sykepleie, Høgskolen i Oslo og Akershus hvordan kostnadsbesparelse og økt produktivitet med bakgrunn i amerikansk management-tenkning etter hvert har influert helsesektoren som annen offentlig forvaltning (2). Her knyttes ledernes lojalitet til organisasjonen, og til å tilfredsstille måloppnåelse og effektivitet $i$ organisasjonen på økonomiske premisser. Konfliktene oppstår fordi sykepleiere og leger har (bør ha!) sin lojalitet og sin faglige og verdimessige forankring knyttet til pasientenes ve og vel. Det er også essensen i artikkelen fra varsleren.

Konklusjonen til Berit Foss er at leger bør være representert i ledelsen av sykehusene. Men skal vi tro varsleren (som tydeligvis skriver av egen dyrekjøpt erfaring) er dette ingen garanti for en pasienten-i-sentrum-tenkning. Det sitter allerede leger på begge sider av bordet, og varsleren går langt $\mathrm{i} a ̊$ antyde at de legene som havner i lederposisjoner, er de som ikke ser utfordringene/har egenskapene som passer for arbeid med pasienter eller eventuelt med forskning. Vi er vant til å tenke på personer i helseyrket som omsorgspersoner, verdimessig knyttet til pasientene i deres ulike, sårbare situasjoner. Dersom utviklingen går i retning av sykehusansatte som produksjonsarbeidere, er det alvorlig. Vi skal være meget takknemlig for de av sykehusenes helsepersonell som våger å stå frem og opponere mot en slik utvikling. Artikkelen gir et skremmende bilde av hvor effektivt ledere kan isolere og uskadeliggjøre en enkelt varsler. Det vil de ikke klare dersom dere blir mange. Som etter hvert potensiell pasient setter jeg min lit til at et anerkjent ressurssterkt helsepersonell ikke sitter passivt som tilskuere til sykehus hvor omsorgsfunksjonen etter hvert kommer i annen rekke.

\section{Olav Hjeljord}

olav.hjeljord@umb.no

Olav Hjeljord (f. 1941) er professor emeritus fraUniversitetet for miljø og biovitenskap, Ås.

Ingen oppgitte interessekonflikter.

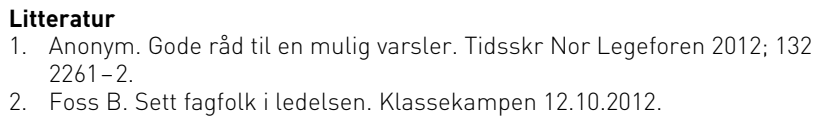

Publisert som rask respons i nettutgaven 14.10. 2012

\section{Oppgulp fra en anonym forfatter}

Jeg må si jeg ble svært overrasket over at artikkelen «Gode råd til en mulig varsler» i Tidsskriftet nr. 20/2012 ble publisert, sågar også anonymt. For meg syntes artikkelen å være bittert, nærmest injurierende og ondsinnet oppgulp fra en person som ikke våger stå frem med sitt navn (1). Selv har jeg arbeidet utenfor sykehussektoren siden midten av 1970-årene, så jeg skal ikke påstå at jeg kjenner dette vesenet, utover kontakter som allmennlege tidligere og ikke minst fra mediene det seneste tiåret. At det er vanskelig å drive og styre sykehus, skjønner jeg godt, men jeg har fortsatt tro på at man gjør så godt man kan. Legeforeningen har vel i alle år oppfordret leger til å ta lederansvar og skaffe seg lederutdanning. I annet avsnitt $i$ artikkelen gir forfatteren en helt utilbørlig karakteristikk av leger som har ønsket å ta slikt ansvar. Her synes jeg faktisk redaksjonen har sviktet som har publisert dette, og sågar latt forfatteren være anonym.

Legeforening og helsemyndigheter har vel lenge oppfordret til å varsle om feil som skjer i helsevesenet. Jeg kan godt skjønne at man skal ha sterk rygg og mot til å gjøre det. For meg synes det som forfatteren har hatt en ubehagelig erfaring knyttet til varsling. Jeg kan skjønne at vedkommende derfor kvier seg for å stå frem med sitt navn, men å skrive en så ekstremt anklagende artikkel uten å oppgi sitt navn synes jeg er lavmål.

Øistein Løvoll

oilovoll@gmail.com

Øistein Løvoll (f. 1945) er pensjonert lege, spesialist i samfunnsmedisin. Ingen oppgitte interessekonflikter.

Litteratur

1. Anonym. Gode råd til en mulig varsler. Tidsskr Nor Legeforen 2012; 132 $2261-2$.

Publisert som rask respons i nettutgaven 6.11. 2012.

\section{Redaksjonen svarer:}

Gode råd til en mulig varsler ble publisert som kommentarartikkel i Tidsskriftet nr. 20/2012 (1). I de sosiale mediene fikk artikkelen stor oppmerksomhet, den ble mest delt og fikk også flest lesere på Tidsskriftets nettside (2). I tillegg har flere kolleger kontaktet redaksjonen med ris og ros for at vi publiserte denne artikkelen. Den har altså vakt interesse hos mange og gitt opphav til ulike reaksjoner. De ulike reaksjonene speiles også i innleggene til Olav Hjeljord og Øistein Løvoll. 
Teksten ble grundig vurdert i redaksjonen før publisering, og forfatterens ønske om anonymitet var godt begrunnet. Fra tid til annen publiserer vi anonyme innlegg. Årsaken til at forfatterne ønsker anonymitet kan variere (3). Da en mor beskrev belastningen ved å få vite at barna hennes hadde «risikogener» for diabetes, var det et rimelig ønske å være anonym, av hensyn til barna (4), på samme måte som da en rusmisbruker fortalte sin historie (5), osv.

Ut fra en totalvurdering mener vi at historien som beskrives i Gode råd til en mulig varsler er tankevekkende og lesverdig, men vi innser at det vil være ulike oppfatninger om dette.

\section{Erlend Hem}

erlend.hem@medisin.uio.no

Erlend Hem (f. 1970) er dr.med. og assisterende sjefredaktør i Tidsskriftet.

\section{RETTELSE}

De allestedsnærværende reseptorene

Kristin Viste, Gunnar Mellgren

Tidsskr Nor Legeforen 2012; 132: 2585

I Tidsskriftet nr. 23-24/2012 side 2585 skal stikktittelen være: Mens årets nobelpris i fysiologi eller medisin går til fremtidens medisin, premierer nobelprisen i kjemi oppdagelsen av G-proteinkoblede reseptorer, som spiller en viktig rolle i dagens medisin

Den ene pristakerens navn er stavet feil i 2. linje første avsnitt og i 2. linje femte avsnitt. Riktig skrivemåte er Kobilka.

Vi beklager feilene, de er rettet på nett.

\section{Litteratur}

1. Anonym. Gode råd til en mulig varsler. Tidsskr Nor Legeforen 2012; 132:

2261-2.

2. Siden sist. Tidsskr Nor Legeforen 2012; 132: 2137.

3. Hem E. Den personlige opplevelsen. Tidsskr Nor Legeforen 2008; 128: 677.

4. Anonym. Gentesting - en belastning for pårørende. Tidsskr Nor Lægeforen 2007; 127: 1824

5. Anonym. 112 dager om våren. Tidsskr Nor Legeforen 2012; 132: 2651-2 